\title{
Studi Pengaruh Kendaraan Parkir Pada Badan Jalan terhadap Kecepatan Arus Lalulintas di Jalan Slamet Riyadi
}

\author{
${ }^{1}$ Fakhrul Rozi Yamali, ${ }^{2}$ Kiki Rizky Amalia, ${ }^{3}$ M.Akbar Zuhri \\ 1,2 Dosen Fakultas Teknik Sipil Universitas Batanghari \\ ${ }^{3}$ Mahasiswa Teknik Sipil Universitas Batanghari \\ Email: fakhrul65@yahoo.co.id
}

\begin{abstract}
Abstrak
Penelitian ini bertujuan untuk mengetahui pengaruh kendaraan yang parkir di badan jalan terhadap karakteristik arus lalulintas di ruas jalan kolektor dengan studi kasus Jalan Slamet Riyadi. Data yang perlu dikumpulkan berupa survai arus lalulintas dan survai waktu tempuh kendaraan. Dalam penelitian ini membagi menjadi dua segmen. Segmen pertama adalah segmen jalan dengan kondisi jalan tanpa adanya kendaraan parkir dibadan jalan. Segmen kedua adalah bagian segmen jal an dengan kondisi terdapat kendaraan parkir diatas badan jalan. Analisa pengaruh kendaraan parkir pada karakteristiik arus lalulintas dilakukan dengan pembandingan antara karakteristik arus lalulintas kedua kondisi tersebut. Hasil penelitian ini menunjukan bahwa terdapat pengaruh kendaraan yang parkir dibadan jalan terhadap karakteristik kecepatan dan karakteristik volume lalulintas.
\end{abstract}

Kata Kunci : Kendaraan parkir, Karakteristik Arus Lalulintas.

\section{PENDAHULUAN}

Pembangunan fisik diwilayah perkotaan seperti pembangunan pertokoan, tempat pendidikan, dan berbagai bangunan lainya, telah mengakibatkan terjadinya perubahan tata guna lahan di sepanjang jalan perkotaan di kota Jambi. Kondisi lain dapat juga dilihat pada beberapa wilayah perkotaan di kota Jambi yaitu banyaknya terjadi perubahan tata guna lahan pada sisi kiri dan sisi kanan badan jalan yang belum diimbangi dengan penyediaan fasilitas parkir untuk kendaraan bermotor yang mencukupi, salah satunya pada ruas Jalan Slamet Riyadi fasilitas parker yang ada belum mencukupi bagi para pengunjung.

Kondisi ini mengakibatkan berkuranganya lebar manfaat jalan untuk kendaraan yang melalui arus lalulintas pada ruas jalan tersebut.

\section{METODE PENELITIAN}

Dalam melakukan pengumpulan data lalulintas, dilakukan dengan cara menghitung secara manual. Perhitungan data volume lalulintas, data waktu tempuh kendaraan dan data volume kendaraan parkir pada badan jalan dipergunakan peralatan sebagai berikut :

1. Formulir survei, yang terdiri dari formulir survei volume lalulintas, formulir survei waktu tempuh kendaraan dan formulir survei parkir kendaraan roda empat pada badan jalan.

2. Penghitungan manual yang dilakukan pada setiap surveyor, yang dilakukan untuk menghitung jumlah dari setiap jenis kedaraan yang melintasi titik pengamatan pada ruas jalan pada periode waktu pengamatan.

3. Meteren dengan panjang 50 (lima puluh) meter, yang dipergunakan untuk mengukur geometrik jalan yang meliputi lebar kontruksi perkerasan jalan, lebar trotoar jalan serta mengukur panjang segmen jalan untuk data waktu tempuh kendaraan dan segmen panjang jalan untuk lokasi perhitungan volume kendaraan parkir.

4. Stopwatch atau alat mengukur waktu dengan ketelitian 1/100 detik yang dipergunakan untuk mengukur waktu tempuh sebagai jenis atau kelompok kendaraan pada segmen jalan sepanjang STA.0+100 meter.

5. Arloji yang dipergunakan untuk menghitung atau mengukur priode waktu pengumpulan data dengan interval waktu per 15 menit pada setiap waktu pengamatan 
jam sibuk pagi, siang, sore serta untuk mengetahui waktu kendaraan masuk dan waktu kendaraan keluar lokasi parkir.

6. Papan triplek ukuran lebar $25 \mathrm{~cm}$ dan panjang $35 \mathrm{~cm}$ yang mempunyai penjepit pada bagian atasnya yang dipergunakan sebagai alas untuk menulis pada formulir survei.

7. Kamera sebagai alat untuk mendokumentasikan segala kegiatan dan kondisi di lapangan

8. Alat tulis lainnya seperti kertas HVS, pena, pensil, dan penggaris.

9. Discord, aplikasi pada telepon seluler, aplikasi ini berguna untuk mengukur kecepatan jarak tempuh kendaraan sepanjang ruas Jl.Slamet Riyadi dari STA0+00-STA0+100, dan membutuhkan 4 (empat) surveyor untuk memegang Discord tersebut dengan berbeda arah jalan.

Data lainnya yang dibutuhkan adalah data :

1. Data geometrik ruas jalan, yang meliputi panjang jalan, lebar perkerasan jalan, lebar jalur, lebar dan jumlah lajur lalulintas serta lebar trotoar jalan.

2. Data kelompok kendaraan dan volume setiap kelompok kendaraan pada setiap periode waktu pengamatan. Data ini dipergunakan untuk mengetahui volume maksimum atau arus lalulintas jam puncak pada setiap priode waktu pengamatan yaitu pada priode waktu jam puncak pagi, siang, dan sore hari.

3. Data waktu tempuh kendaraan untuk segmen ruas jalan sepanjang STA.0+50 meter dimana data ini dipergunakan untuk menghitung kecepatan rata-rata ruang (Us) dari arus lalulintas pada ruas jalan tersebut pada setiap priode waktu jam puncak pagi, siang, dan sore hari.

4. Data kendaraan roda empat yang masuk dan keluar lokasi parkir pada kedua sisi badan jalan sepanjang STA.0+500 meter. Data ini dipergunakan untuk menghitung dan melakukan analisa terhadap pengaruh kecepatan rata-rata ruang (Us) akibat berkurangnya lebar badan jalan afektif.

Data volume lalulintas dan waktu tempuh kendaraan tersebut dikelompokan menurut kelompok kendaraan yang terdiri atas :

1. Kelompok kendaraan ringan (KR) yang terdiri dari kendaraan bermotor roda 4 (empat).

2. Kelompok kendaraan berat (KB) yang terdiri dari kendaraan bermotor roda 6 (enam).

3. Kelompok kendaraan sepeda motor (SMP) yaitu kendaraan bermotor beroda 2 (dua) atau beroda 3 (tiga).

\section{METODE PENELITIAN}

Penelitian ini dilakukan dengan cara survai. Secara urutan, alur penelitian ini sebagaimana diagram alir berikut ini. 


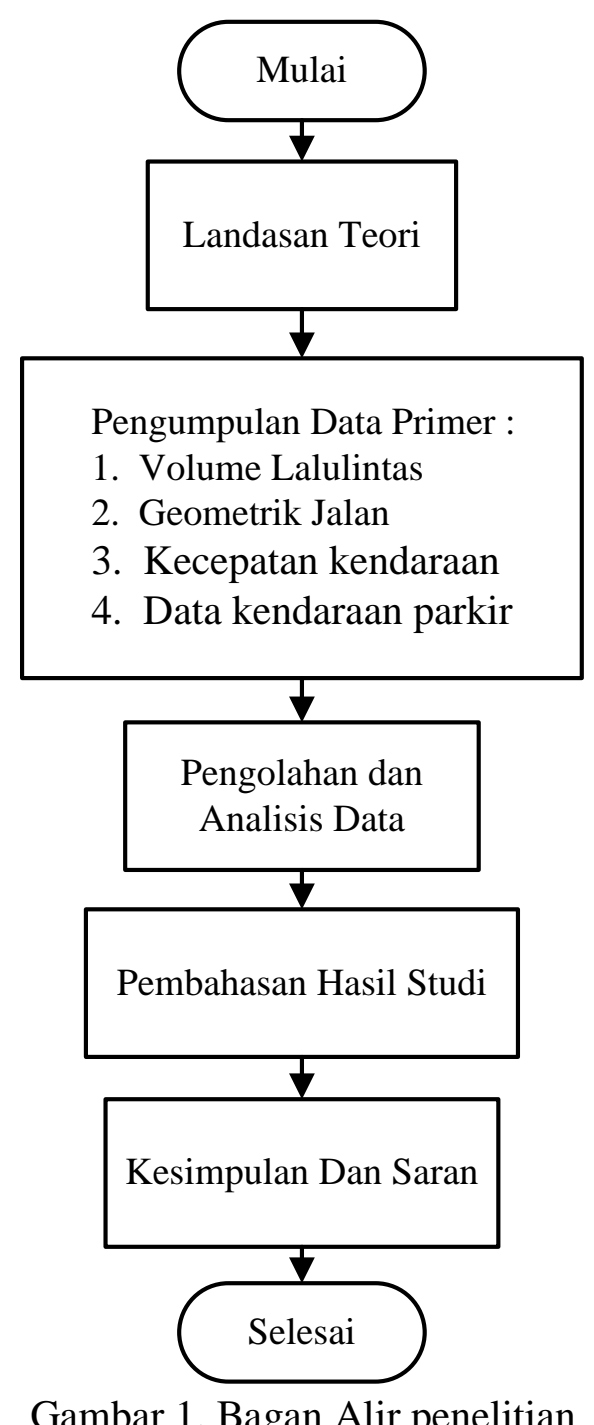

\section{HASIL DAN PEMBAHASAN}

Ruas Jl. Slamet Riyadi kota Jambi yang membentang arah utara ke selatan. Berdasarkan hasil pengukuran geometrik ruas jalan pada lokasi studi yang meliputi panjang jalan, lebar perkerasan jalan, lebar jalur lalulintas, lebar dan jumlah lajur lalulintas dan lebar saluran drainase, maka diperoleh hasil sebagai berikut :

Tabel 1 : Geometrik ruas Jl. Slamet Riyadi Kota Jambi

\begin{tabular}{|c|c|c|c|c|c|}
\hline \multirow[t]{2}{*}{ Nama Jalan } & \multirow{2}{*}{$\begin{array}{l}\text { Panjang Jalan } \\
\text { (Mtr) }\end{array}$} & \multicolumn{4}{|c|}{ Lebar Bagian Jalan (Meter) } \\
\hline & & Perkerasan & Lajur Lalulintas & Trotoar & Drainase \\
\hline Jl.Slamet Riyadi & 2.500 .00 & 14.00 & $4 \times 3.65$ & $2 \times 1.33$ & $2 \times 1.00$ \\
\hline
\end{tabular}

Sumber : Hasil Pengukuran,2018

Potongan melintang dan tampak atas ruas Jl. Slamet Riyadi Kota Jambi berdasarkan hasil pengukuran yang telah dilaksanakan, dapat dijelaskan sebagaimana gambar berikut : 

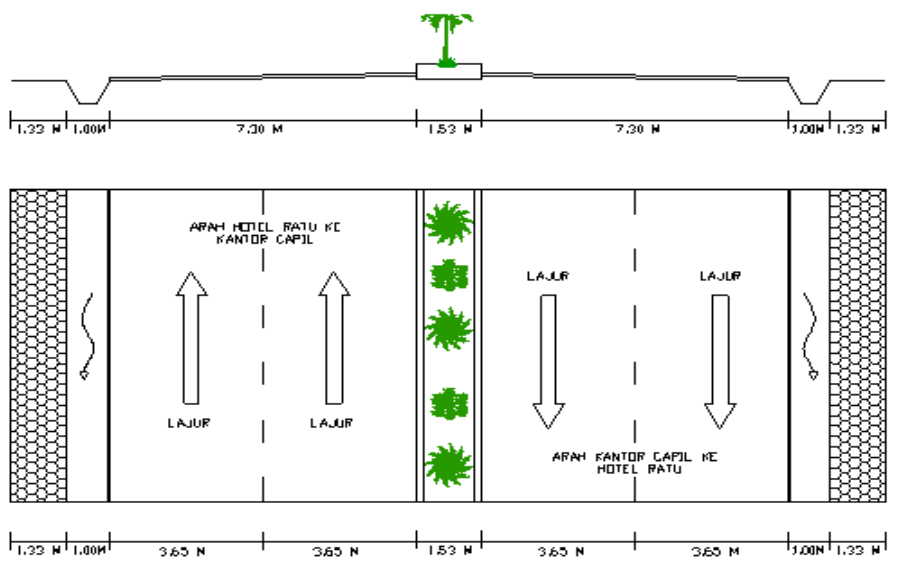

Gambar 2 : Potongan Melintang Jl.Slamet Riyadi Kota Jambi

Sumber : Hasil pengukuran di Lapangan, 2018

Marka jalan yang berfungsi untuk pemisah arah lalulintas yang terletak pada bagian tengah badan jalan merupakan garis ganda yang terdiri dari garis lurus terputus-putus dan garis lurus tidak terputus-putus, jika dilihat dari arah bundaran simpang empat menuju pintu masuk hotel shang ratu maka letak garis terputus-putus ada pada sisi kiri dan garis tidak terputus ada pada sisi kanan dengan lebar garis $10 \mathrm{~cm}$ baik untuk garis terputus-putus dan garis lurus serta panjang garis terputus-putus 2,00 m. Untuk marka jalan yang berfungsi sebagai pemisah lajur lalulintas pada setiap jalur lalulintas merupakan garis tunggal yaitu berupa garis lurus terputus-putus dengan lebar $10 \mathrm{~cm}$ dan panjang 2,00 $\mathrm{m}$.

Dan terdapat kemacetan pada pengamatan studi ini pada ruas Jl. Slamet Riyadi pada saat kendaraan menikung atau memutar pada bagian ruas jalan yang terputus seperti gambar berikut :
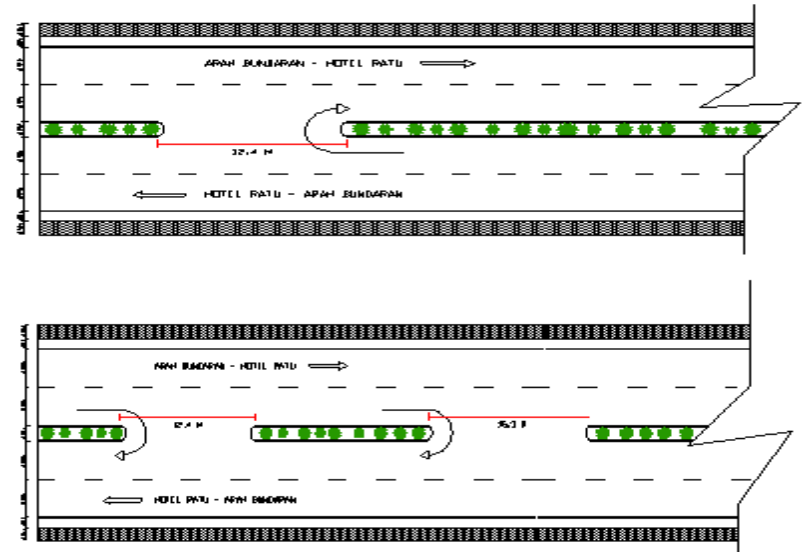

Gambar 3 : denah tampak atas ruas jalan pada ruas Jl.Slamet Riyadi

Sumber : Hasil pengolahan data, 2018

\section{Volume Lalulintas}

Berdasarkan hasil survei yang telah dilaksanakan pada 7 (tujuh) hari maka ditetapkan hari terpadat untuk volume lalulintas pada hari Rabu pada tanggal 17 oktober 2018 selama 7 jam, yang terdiri dari jam sibuk pagi pada pukul 08.00 - 10.00 WIB atau selama 2 (dua) jam, jam sibuk siang hari pada pukul $11.00-14.00 \mathrm{WIB}$ atau selama 3 (tiga) jam, kemudian jam sibuk sore hari pada pukul 15.00 - 17.00 WIB, atau selama 2 (dua) jam, dengan perhitungan setiap jenis atau kelompok kendaraan secara manual dan setelah dilakukan analisa serta perhitungan data hasil survei, maka didapat volume lalulintas untuk ruas Jl. Slamet Riyadi.

Berdasarkan volume lalulintas hasil survei yang dihitung dalam satuan kendaraan per jam, selanjutnya ditentukan nilai faktor ekivalen mobil penumpang (faktor emp) menurut ketentuan dalam MKJI, 1997 yaitu sebagai berikut : 
1. Sepeda Motor

2. Kendaraan Ringan (KR)

3. Kendaraan Berat (KB)

Berdasarkan volume lalulintas dalam satuan kendaraan per jam tersebut, dilakukan perhitungan dengan mempergunakan faktor emp untuk mendapatkan volume lalulintas dalam satuan smp/jam. Perhitungan volume lalulintas dari satuan kendaraan/jam menjadi satuan smp/jam dapat dilakukan dengan cara mengalikan volume hasil survey dengan faktor emp, sebagai mana contoh perhitungan dibawah ini yaitu untuk periode jam survei pada pukul 08.00-09.00 WIB, diperoleh hasil sebagai berikut :

Tabel 2 : Jumlah Smp/jam

\begin{tabular}{llcc}
\hline No & Kendaraan & Jumlah kend x emp & Hasil Jumlah Smp/Jam \\
\hline 1 & Sepeda Motor & $945 \times 0,4$ & 378 \\
2 & Kendaraan Ringan & $402 \times 1,0$ & 402 \\
4 & Kendaraan Berat & $18 \times 1,3$ & 23,4 \\
& Jumlah & 1365 & 803 \\
\hline
\end{tabular}

Sumber : Hasil Penelitian, 2018

Tabel 3 : Volume Lalulintas Ruas Jl. Slamet Riyadi Untuk Arah Lalulintas dari Hotel Shang Ratu menuju Bundaran Simpang Empat

\begin{tabular}{cccccc}
\hline $\begin{array}{c}\text { Waktu } \\
\text { Survey }\end{array}$ & \multicolumn{2}{c}{ Jenis/kelompok dan jumlah kendaraan } & \multicolumn{2}{c}{ Volume Lalulintas } \\
Sepeda Motor & Kend Ringan & Kend Berat & Kend/Jam & Smp/Jam \\
\hline $08.00-09.00$ & 945 & 402 & 18 & 1365 & 803 \\
$09.00-10.00$ & 1820 & 624 & 24 & 2468 & 1383 \\
$10.00-11.00$ & 1540 & 634 & 6 & 2180 & 1257 \\
$11.00-12.00$ & 2063 & 604 & 10 & 2677 & 1442 \\
$12.00-13.00$ & 1073 & 463 & 3 & 1539 & 896 \\
$13.00-14.00$ & 1040 & 500 & 16 & 1556 & 936 \\
$14.00-15.00$ & 1360 & 730 & 18 & 2108 & 1297 \\
$15.00-16.00$ & 2160 & 897 & 20 & 3077 & 1787 \\
$16.00-17.00$ & 2560 & 1104 & 14 & 3678 & 1138 \\
\hline
\end{tabular}

Sumber : Hasil survey dan analisa data, 2018

Tabel 4 : Volume Lalulintas Ruas Jl. Slamet Riyadi Untuk Arah Lalulintas dari Bundaran Simpang Empat Menuju Hotel Shang Ratu

\begin{tabular}{cccccc}
\hline & \multicolumn{2}{c}{ Jenis/kelompok dan jumlah kendaraan } & \multicolumn{2}{c}{ Volume Lalulintas } \\
Waktu Survey & Sepeda Motor & Kend. Ringan & Kend Berat & Kend/Jam & Smp/Jam \\
\hline $08.00-09.00$ & 580 & 290 & 15 & 885 & 541 \\
$09.00-10.00$ & 1030 & 745 & 20 & 1795 & 1183 \\
$10.00-11.00$ & 1145 & 660 & 15 & 1820 & 1137 \\
$11.00-12.00$ & 1225 & 710 & 12 & 1947 & 1215 \\
$12.00-13.00$ & 1375 & 523 & 15 & 1913 & 1079 \\
$13.00-14.00$ & 1720 & 623 & 22 & 2365 & 1339 \\
$14.00-15.00$ & 1700 & 615 & 15 & 2330 & 1314 \\
$15.00-16.00$ & 1390 & 207 & 7 & 1604 & 772 \\
$16.00-17.00$ & 1128 & 820 & 22 & 1970 & 1299 \\
\hline
\end{tabular}

Sumber : Hasil survey dan analisa data, 2018

Tabel 5 : Volume Lalulintas Ruas Jl. Slamet Riyadi Untuk 2 (dua) Arah

\begin{tabular}{|c|c|c|c|c|c|}
\hline \multirow{2}{*}{$\begin{array}{l}\text { Waktu } \\
\text { Survey }\end{array}$} & \multicolumn{3}{|c|}{ Jenis/kelompok dan jumlah kendaraan } & \multirow{2}{*}{$\begin{array}{c}\text { Volume Lalulintas } \\
\text { Kend/Jam }\end{array}$} & \multirow[b]{2}{*}{ Smp/Jam } \\
\hline & Sepeda Motor & Kend. Ringan & Kend Berat & & \\
\hline $08.00-09.00$ & 1525 & 692 & 33 & 2250 & 1344 \\
\hline $09.00-10.00$ & 2850 & 1369 & 44 & 4263 & 2566 \\
\hline $10.00-11.00$ & 2685 & 1294 & 21 & 4000 & 2395 \\
\hline $11.00-12.00$ & 3288 & 1314 & 22 & 4624 & 2657 \\
\hline $12.00-13.00$ & 2448 & 986 & 18 & 3452 & 1988 \\
\hline
\end{tabular}


Studi Pengaruh Kendaraan Parkir Pada Badan Jalan terhadap Kecepatan Arus Lalulintas di Jalan Slamet Riyadi

\begin{tabular}{llllll}
\hline $13.00-14.00$ & 2760 & 1123 & 38 & 3921 & 2276 \\
$14.00-15.00$ & 3060 & 1345 & 33 & 4438 & 2611 \\
$15.00-16.00$ & 3550 & 1104 & 27 & 4681 & 2559 \\
$16.00-17.00$ & 3688 & 1924 & 36 & 5648 & 3445 \\
\hline
\end{tabular}

Sumber : Hasil survey dan analisa data, 2018

Bedasarkan hasil survei dan analisa data pada tabel tersebut dapat diketahui bahwa komposisi arus lalulintas Jl. Slamet Riyadi, kendaraan yang paling dominan adalah sepeda motor (SM) dan kendaraan ringan (KR), dimana perbandingan komposisi ketiga kelompok kendaraan tersebut, rata-rata prosentasenya adalah sebagai berikut :

$$
\frac{\text { Jumlah kendaraan }}{\text { Jumlah keseluruhan }} \times 100 \%
$$

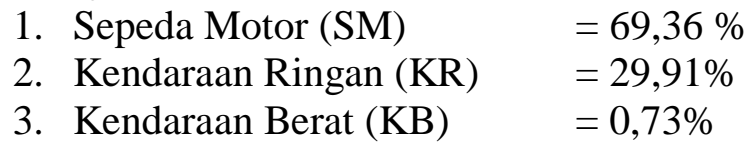

Sumber : Hasil Penelitian,2018

\section{Gambar 4 : Grafik fluktuasi arus lalulintas dalam kend/jam}

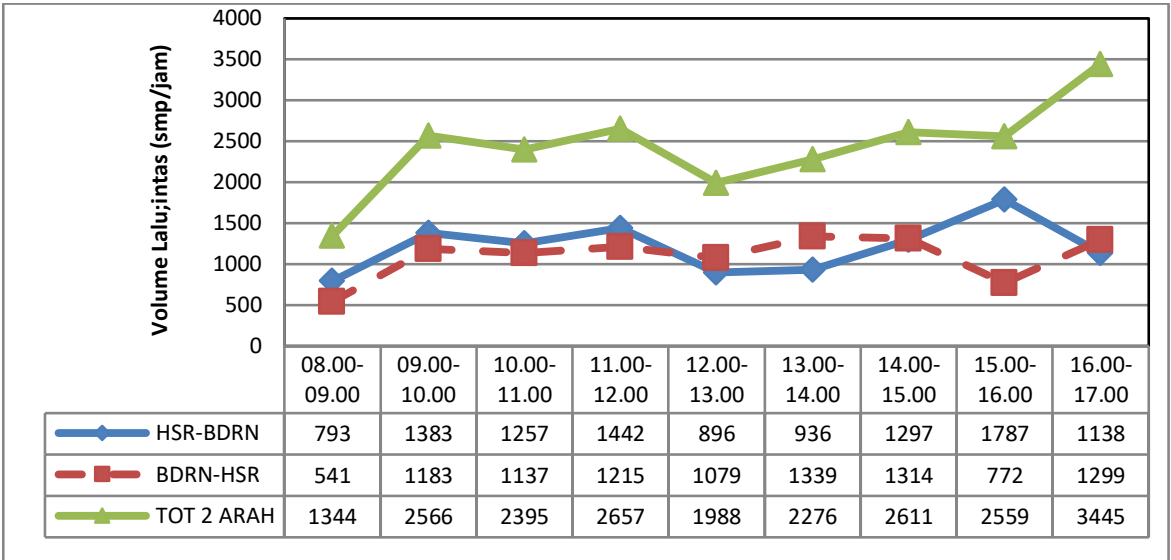

Gambar 5 : Grafik fluktuasi arus lalulintas dalam smp/jam

Sumber : Hasil Penelitian,2018

Keterangan : HSR : Hotel Shang Ratu

BDR : Bundaran 
Untuk menghitung kecepatan rata-rata ruang (Us), dapat dihitung dengan persamaan:

Us = Jumlah jarak tempuh seluruh kendaraan / Jumlah waktu tempuh seluruh Kendaraan

Tabel 6 : Kecepatan rata-rata ruang (Us) arus lalulintas diruas Jl. Slamet Riyadi pada beberapa jam puncak

\begin{tabular}{lccc}
\hline Arah Lalulintas & \multicolumn{2}{c}{ Kecepatan Rata-rata Ruang (Us) (Km/jam) } \\
\cline { 2 - 4 } & Pagi & Siang & Sore \\
\hline Bundaran - H. Shang Ratu & & & 25 \\
Minimum & 20 & 21 & 35 \\
Maksimum & 30 & 22 & 25 \\
\hline H. Shang Ratu - Bundaran & & & 35 \\
Minimum & 20 & 20 & 25 \\
Maksimum & 35 & & \\
\hline
\end{tabular}

Sumber : Hasil Analisa Data, 2018

\section{Kecepatan Arus Lalulintas}

Berdasarkan hasil pengukuran waktu tempuh untuk segmen panjang jalan 100 meter selama priode jam puncak pagi siang dan sore hari, yang kemudian dilakukan perhitungan dengan menggunakan analisis Space Mean Speed atau kecepatan rata-rata ruang (Us), diperoleh sebagaimana berikut :

Dengan hasil penelitian tabel diatas dengan adanya kendaraan yang parkir pada badan jalan mengakibatkan kecepatan rata-rata pada kecepatan kendaraan pada jam puncak pagi hari dapat mencapai $20 \mathrm{~s} / \mathrm{d} 35 \mathrm{~km} / \mathrm{jam}$, dan pada jam puncak siang hari dapat mencapai $20 \mathrm{~s} / \mathrm{d}$ $25 \mathrm{~km} / \mathrm{jam}$, dan pada jam puncak sore hari dapat mencapai kecepatan $25 \mathrm{~s} / \mathrm{d} 35 \mathrm{~km} / \mathrm{jam}$. Sedangkan dengan kecepatan rata-rata dengan tidak adanya kendaraan yang parkir pada badan jalan kecepatan kendaraan mencapai kecepatan pada normalnya dengan mencapai 40 s/d 50 km/jam pada setiap jam-jam puncaknya.

\section{Kepadatan Lalulintas}

Untuk menghitung kepadatan lalulintas yang terjadi pada ruas Jl. Slamet Riyadi, maka dihitung kepadatan lalulintas untuk total 2 (dua) arah, hal ini dikarenakan tipe Jl. Slamet Riyadi adalah 4/2 D. Selanjutnya hasil perhitungan kepadatan lalulintas ruas Jl. Slamet Riyadi adalah sebagai berikut :

$$
\begin{aligned}
& \mathrm{D}=\mathrm{Q} / \mathrm{Us}(\mathrm{Smp} / \mathrm{km}) \\
& \mathrm{Q}=\text { Volume arus lalulintas }(\mathrm{Smp} / \mathrm{jam}) \\
& \text { Us }=\text { Kecepatan rata-rata Ruang }(\mathrm{km} / \mathrm{jam})
\end{aligned}
$$

Tabel 7 : Kepadatan Arus Lalulintas di Ruas Jl. Slamet Riyadi Pada Beberapa Jam Puncak

\begin{tabular}{lccc}
\hline \multicolumn{1}{c}{ Arah Lalulintas Total 2 Arah } & \multicolumn{3}{c}{ Kepadatan Lalulintas (smp/km) } \\
\cline { 2 - 4 } & Pagi & Siang & Sore \\
\hline Minimum & 13,44 & 19,88 & 25,59 \\
Maksium & 25,66 & 26,57 & 34,45 \\
\hline
\end{tabular}

Sumber : Hasil Analisa Data, 2018

Dari hasil perhitungan survei volume lalulintas pada jam puncak pagi,siang dan sore hari didapatkan hasil minimum dan maksimum yang dimana pada pagi hari kepadatan kendaraan tidak terlalu padat di bandingkan pada jam puncak sore hari.

\section{Parkir Kendaraan Pada Badan Jalan}

Peggunaan tepi jalan yaitu lajur paling pinggir disepanjang Jl. Slamet Riyadi dengan panjang segmen jalan yang diamati adalah sepanjang $300 \mathrm{M}$ pada kedua sisi (kiri dan kanan) sebagai tempat parkir kendaraan roda 4 oleh setiap pengunjung pertokoan dan perguruan tinggi di sepanjang Jl. Slamet Riyadi adalah sebagai berikut: 
Studi Pengaruh Kendaraan Parkir Pada Badan Jalan terhadap Kecepatan Arus Lalulintas di Jalan Slamet Riyadi

Tabel 8 : Jumlah dan lama waktu parkir kendaraan roda empat pada tepi Jl. Slamet Riyadi pada beberapa jam puncak

\begin{tabular}{lcccc}
\hline \multicolumn{1}{c}{ Jam puncak } & $\begin{array}{c}\text { Jumlah kend roda 4 yang parkir } \\
\text { (kend/jam/100) }\end{array}$ & \multicolumn{2}{c}{ Lama waktu parkir (menit) } \\
\cline { 3 - 5 } & & Minimum & Maksimum & Rata-rata \\
\hline Pagi hari & $26 \mathrm{~s} / \mathrm{d} \mathrm{50}$ & 5 & 12 & 8,5 \\
\hline Siang hari & $59 \mathrm{~s} / \mathrm{d} \mathrm{73}$ & 5 & 25 & 17,5 \\
\hline Sore hari & $87 \mathrm{~s} / \mathrm{d} \mathrm{132}$ & 8 & 17 & 16,5 \\
\hline
\end{tabular}

Sumber : Hasil Analisa Data, 2018

Dari tabel tersebut diatas diketahui bahwa jumah dan lamanya waktu parkir kendaraan 4 pada tepi jalan pada jam puncak pagi lebih kecil dibandingkan pada jam puncak siang, ataupun sore hari. Pada jam puncak sore hari diketahui bahwa jumlah kendaraan parkir pada tepi jalan semakin meningkat dan lamanya waktu parkir juga semakin bertambah, dimana hal tersebut juga menggambarkan meningkatnya berbagai aktivitas dan pergerakan masyarakat disekitar lokasi penelitian.

\section{Kinerja Ruas Jalan Pada Kondisi Saat Ini}

Kinerja ruas jalan dihitung berdasarkan Manual Kapasitas Jalan Indonesia MKJI, 1997 dimana parameter yang akan ditinjau adalah diantaranya adalah perbandingan volume terhadap kapasitas (Q/C rasio) Kapasitas ruas jalan dihitung dengan persamaan :

\section{C = Co $\times$ FCw $\times$ FCsp $\times$ FCsf $\times$ FCes (smp/jam)}

Dimana :

$\mathrm{C}=$ Kapasitas dalam smp/jam

Co = Kapasitas dasar dalam smp/jam (MKJI, 1997)

$\mathrm{FCw}=$ Faktor penyesuaian lebar jalur LL (MKJI, 1997)

FCsp = Faktor penyesuaian pemisah arah (MKJI, 1997)

FCsf = Faktor penyesuaian hambatan samping (MKJI, 1997)

FCcs $=$ Faktor penyesuaian ukuran kota (MKJI, 1997)

Perhitungan kapasitas untuk ruas Jl. Slamet Riyadi sebagai tabel berikui ini :

Tabel 9 : Perhitungan Kapasitas ruas jalan

\begin{tabular}{cccccccc}
\hline $\begin{array}{c}\text { Co } \\
\text { Smp/Jam }\end{array}$ & FCw & FCsp & FCsf & FCcs & $\begin{array}{c}\text { C } \\
\text { Smp/jam }\end{array}$ & $\begin{array}{c}\text { Jumlah } \\
\text { Lajur Efektif }\end{array}$ & $\begin{array}{c}\text { C Total } \\
\text { smp/jam }\end{array}$ \\
\hline 1650 & 1,00 & 1,00 & 0,92 & 0,90 & 1366 & 2 & 2732 \\
\hline
\end{tabular}

Sumber : Hasil penelitian, 2018

Dari tabel diatas diketahui bahwa kapasitas efektif untuk ruas Jl. Slamet Riyadi adalah 2732 smp/jam, dengan demikian nilai Q/C rasio untuk lalulintas 2 (dua) arah dapat dihitung sebagai berikut :

1. Periode jam puncak pagi $\quad \mathrm{Q} / \mathrm{C}=2566 / 2732=0,939$

2. Periode jam puncak siang $\mathrm{Q} / \mathrm{C}=2657 / 2732=0,972$

3. Periode jam puncak sore $\mathrm{Q} / \mathrm{C}=3445 / 2732=1,261$

Perameter selanjutnya yang harus dihitung untuk menentukan kinerja ruas jalan adalah kecepatan arus bebas, yaitu :

$=(F V O+F V w) \times$ FFVcs $(\mathrm{km} / \mathrm{jam})$

$\mathrm{FV}=$ Kecepatan arus bebas kend ringan pad kend lapangan $(\mathrm{km} / \mathrm{jam})$

FVo $\quad=$ Kecepatan arus bebas dasar kend ringan (MKJI, 1997)

FVw = Penyesuaian kecepatan untuk lebar jalan (MKJI, 1997) 
Studi Pengaruh Kendaraan Parkir Pada Badan Jalan terhadap Kecepatan Arus Lalulintas di Jalan Slamet Riyadi

FFVsf $\quad=$ Faktor penyesuaian untuk hambatan samping dan kereb (MKJI, 1997)

FFVcs = Faktor penyesuaian untuk kota (MKJI, 1997)

Tabel 10 : Perhitungan kecepatan arus bebas

\begin{tabular}{ccccc}
\hline Fvo $(\mathrm{Km} / \mathrm{jam})$ & FVw & FFVsf & FFVcs & FV $(\mathrm{Km} / \mathrm{jam})$ \\
\hline 51 & 2,00 & 0,85 & 0,93 & 52,5 \\
\hline
\end{tabular}

Sumber : Hasil penelitian, 2018

Dari hasil perhitungan tersebut di atas diperoleh kecepatan arus bebas (FV) pada ruas Jl. Slamet Riyadi adalah $52,5 \mathrm{~km} / \mathrm{jam}$, dan kecepatan rata-rata ruang pada setiap jam puncak adalah:

1.Periode jam puncak pagi $\quad$ Us $=20-35 \mathrm{~km} / \mathrm{jam}$

2.Periode jam puncak siang $\quad U s=21-25 \mathrm{~km} / \mathrm{jam}$

3. Periode jam puncak sore $\quad U s=25-35 \mathrm{~km} / \mathrm{jam}$

Berdasarkan hasil analisa Q/C rasio, kepadatan lalulintas, kecepatan rata-rata dan kecepatan arus bebas maka dapat ditentukan kinerja atau tingkat pelayanan jalan untuk ruas Jl. Slamet Riyadi saat ini yaitu :

1. Kondisi pagi $\mathrm{Q} / \mathrm{C}=0,939$ dan siang $\mathrm{Q} / \mathrm{C}=0,972$, maka tingkat pelayananya adalah adalah " $\mathrm{E}$ " dengan rasio $\mathrm{Q} / \mathrm{C}=0,85-1,00$, dimana karakteristiknya volume lalulintas mendekati atau macet berada pada kapasitas, arus tidak stabil dan kecepatan kadang terhenti.

2. Kondisi Sore, $\mathrm{Q} / \mathrm{C}=1,261$, maka tingkat pelayananya adalah adalah " $F$ " dengan rasio $\mathrm{Q} / \mathrm{C}>1,00$, dimana karakteristiknya arus yang dipaksakan atau macet, keeatan rendah, volume dibawah kapasitas, antrian panjang dan terjadi hambatan-hambatan yang besar.

\section{SIMPULAN}

1. Pada survei pengambilan data pada jam-jam puncak diruas Jl.Slamet Riyadi mendapatkan hasil dimana kendaraan yang parkir pada badan jalan mencapai $26 \mathrm{~s} / \mathrm{d} 50$ kendaraan pada jam puncak pagi hari, $59 \mathrm{~s} / \mathrm{d} 73$ kendaraan pada jam puncak siang $87 \mathrm{~s} / \mathrm{d} 132$ kendaraan pada jam puncak sore hari, dengan jumlah kendaraan parkir yang telah didapat mengakibat kan kecepatan kendaraan bermotor menurun dengan kecepatan maksimum $35 \mathrm{~km} / \mathrm{jam}$.

2. Tingkat pelayanan di ruas JL. Slamet Riyadi pada waktu sore hari adalah F, dimana karakteristiknya arus yang dipaksakan atau macet, kecepatan rendah, volume dibawah kapasitas, antrian panjang dan terjadi hambatan-hambatan yang besar.

\section{DAFTAR PUSTAKA}

Adji Sakti, 2011 Perencanaan Pembangunan Transportasi

C.Jotin Khisty dan B.Kent Lall. 2003. Dasar-dasar Rekayasa Transportasi Jilid 1 Edisi Ketiga. Erlangga. Jakarta

Data Jumlah Mahasiswa dan Dosen, 2017-2018 BAAK Universitas Batanghari Jambi

Etty Soesilowati (2008), Tentang Kemacetan Lalulintas

Hobb, FD, 1995, Perencanaan dan Teknik Lalulintas, (terjemahan) Gadjah Mada University Press, Yogyakarta

Iskandar Abubakar (1999), Rekyasa Lalulintas, Pedoman Perencanaan dan Pengoprasian Lalulintas di Wilayah Perkotaan, Ditjen Perhubungan Darat, Depertemen Perhubungan RI, Jakarta

Iskandar Abubakar (1996) Menuju Lalulintas dan Angkutan Jalan Yang Tertib, Ditjen Perhubungan Darat, Depertemen Perhubungan RI, Jakarta

Keputusan Direktur Jendral Perhubungan Darat Nomor : 272/HK.105/DRJD/96 Tentang Pedoman Teknis Penyelengaraan Fasilitas Parkir Tahun 1996 

Riyadi

Manual Kapasitas Jalan Indonesia, Ditjen. Bina Marga Depertemen Perkerjaan Umum RI, Jakarta Pada Tahun 1997

Munawar, 1998 Manajemen Lalulintas, Gadjah Mada Universitas Press, Yogyakarta

Peraturan Pemerintah RI No. 43 Tahun 1993 Tentang Prasarana dan Sarana Lalulintas Jalan, Sekretariat Negara RI, Jakarta

Undang-undangan Republik Indonesia NO. 38 Pasal 1 Ayat 4 Tahun 2004 Tentang Jalan Sekretariat Negara RI, Jakarta 